\title{
HUBUNGAN PENGETAHUAN IBU HAMIL TENTANG KEBERSIHAN GIGI DAN MULUT DENGAN GINGIVITIS PREGNANCY DI PUSKESMAS RANOMUT MANADO
}

\author{
Vega Roosa Fione $e^{1}$ Jeana Lydia Maramis ${ }^{2}$ \\ 1,2) Jurusan Keperawatan Gigi Poltekkes Kemenkes ManadoJl.RW Mongisidi Malalayang II Manado \\ Email : vegaroosafione@gmail.com
}

\begin{abstract}
ABSTRAK
Latar belakang : Sebagian besar ibu hamil menunjukan perubahan pada gusi selama kehamilan akibat kurangnya kesadaran menjaga kebersihan gigi dan mulut. Gusi terlihat lebih merah dan mudah berdarah ketika menyikat gigi, penyakit ini disebut pregnancy gingivitis, biasanya mulai terlihat sejak bulan kedua dan muncul depan mulut. Tujuan penelitian ini untuk mengetahui adanya hubungan pengetahuan tentang kebersihan gigi dan mulut pada ibu hamil terhadap gingivitis precnancy di Puskesmas Ranomut. Metode : Penelitian ini menggunakan metode analitik dengan pendekatan cross sectional study yang dilaksanakan pada bulan Juni 2018 dan berlokasi di Puskesmas Ranomut dengan jumlah sampel 59 ibu hamil dengan menggunakan metode accidental sampling dengan menggunakan kriteria inklusi. Pengetahuan diukur dengan kuesioner dan gingivitis pregnancy diukur dengan indeks gingival. Data yang diperoleh ditabulasi dengan Correlation Kendall Tau. Hasil : analisis menggunakan uji Correlation Kendall Tau didapatkan nilairsebesar -0,441 dengan kekuatan korelasi cukup dengan nilai $p$ sebesar 0,000 lebih kecil dari nilai $\alpha=0,05$ sehingga terdapat nilai korelasi yang bermakna antara variabel pengetahun kebersihan gigi dan mulut terhadap variabel gingivitis pregnancy dengan arah korelasi negatif (-) yang berarti semakin besar nilai pengetahuan kebersihan gigi dan mulut maka semakin kecil nilai gingivitis pregnancy. Kesimpulan : ada hubungan antara variabel bebas dengan variabel terikat.
\end{abstract}

\section{Kata kunci : pengetahuan, kebersihan gigi dan mulut,gingivitis pregnancy}

\section{ABSTRACT}

Background: Most pregnant women show changes in the gums during pregnancy due to a lack of awareness of maintaining dental and oral hygiene. Gums look redder and bleed easily when brushing your teeth, this disease is called pregnancy gingivitis, usually starting to appear since the second month and appearing before the mouth. The purpose of this study was to determine the relationship between knowledge about dental and oral hygiene in pregnant women against gingivitis precnancy at Ranomut Health Center. Method: This study used an analytical method with a cross sectional approach conducted in June 2018 and located in Ranomut Health Center with a sample of 59 pregnant women using the accidental sampling method using inclusion criteria. Knowledge was measured by questionnaires and pregnancy gingivitis was measured by the gingival index. The data was analysed with Correlation Kendall Tau test. Results: analysis using the Kendall Tau correlation test obtained a value of -0.441 with sufficient correlation strength with a $\mathrm{p}$ value of 0.000 smaller than the value of $\alpha=0.05$ so that there is a significant correlation between dental and oral hygiene variables to pregnancy gingivitis variables with a correlation negative (-) which means the greater the value of knowledge of dental and oral hygiene, the smaller the value of gingivitis pregnancy. Conclusion: there is a relationship between the independent variable and the dependent variable.

Key Words : Knowledge, Oral Hygiene, Gingivitis Pregnancy 


\section{PENDAHULUAN}

Kehamilan adalah sebuah proses yang diawali dengan keluarnya sel telur yang telah matang dari indung telur. Kemudian telur itu bertemu dengan sel sperma dari laki - laki. Dengan bertemunya sel telur dan sel sperma maka keduanya akan menyatu dan kemudian akan terus berkembang menjadi janin. ${ }^{1}$ Ibu hamil yang mengalami sakit gigi kronis atau berat dan menderita infeksi periodontal, beresiko untuk melahirkan bayi berat lahir rendah (BBLR) karena pertumbahannya terganggu. Hal ini dikatakan oleh Hearther Jaret, dari University of North Carolina di Chapel Hill, Amerika Serikat dalam presentasinya di Asosiasi Internasional untuk penelitian gigi. Sementara Dr.Steven Offenbacher, Direktur Center of Oral and systemic Diseases di Universitas yang sama menjelaskan bahwa resiko tersebut sama kuatnya dengan resiko akibat merokok atau pemakaian alkohol. ${ }^{2}$

Beberapa penelitian menyebutkan bahwa peningkatan kadar hormone estrogen dan progesteron akan mempengaruhi kesehatan gigi dan mulut, dimana dijumpai bahwa 30-100\% wanita mengalami gingivitis selama periode kehamilan. Kehamilan juga akan meningkatkan risiko terjadinya karies gigi karena adanya perubahan pada lingkungan rongga mulut. $^{3}$ Penelitian yang dilakukan oleh Hidayati (2012) di Puskesmas Andalas Kecamatan Padang menyatakan bahwa hubungan antara tingkat kebersihan gigi dan mulut ibu hamil didapatkan sebagian besar yaitu 3 dari 4 ibu hamil (75\%) mempunyai tingkat kebersihan mulut sedang mengalami gingivitis sedang, sisanya (25\%) mengalami gingivitis berat. $^{4}$

Kehamilan adalah suatu proses fisiologi yang dapat menimbulkan perubahan - perubahan pada tubuh wanita, baik fisik maupun psikis karena pengaruh natural hormon. ${ }^{2}$ Pada wanita hamil, biasanya dapat terjadi perubahan - perubahan sebagai berikut: 1. Perubahan fisiologi (perubahan normal pada tubuh) meliputi : penambahan berat badan, pembesaran pada payudara, bisa terjadi pembekakan pada tangan dan kaki, terutama pada usia kehamilan trimester III ( 6 - 9 bulan), perubahan pada kulit karena adanya kelebihan pigmen pada tempat - tempat tertentu (pipi, sekitar hidung, sekitar puting, susu dan diatas tulang kemaluan sampai pusar), dapat terjadi penurunan $\mathrm{pH}$ saliva. 2 . Perubahan psikis (perubahan yang berhubungan dengan kejiwaan) sering terjadi pada usia kehamilan muda (trimester I atau 0 - 3 bulan) berupa : Morning sickness (rasa mual dan ingin muntah terutama pada waktu pagi hari), rasa lesu, lemas, dan terkadang hilang selara makan, perubahan tingkah laku diluar kebiasaan sehari - hari seperti "ngidam".

Gingivitis pada ibu hamil dimulai pada trimester II kehamilan. Keadaan gingivitis ini mencapai titik keparahan tertinggi pada trimester III, tepatnya pada bulan ke-8. ${ }^{6}$ Jarinngan gingiva ibu hamil dapat mengalamiperadangan. Gingiva kehamilan tampak edematous, hiperplastik, peningkatan pendarahan, serta warnanya menjadi lebih merah terang. Perubahan ini terjadi baik pada area marginal maupun pada papila interdental. Keadaan tersebut dapat bersifat lokal maupun menyeluruh. Gingivitis ini menjadi bertambah parah pada masa kehamilan trimester II dan trimester III. Kasus ini biasa terjadi dengan rentang inflamasi ringan hingga parah, yang akan memperparh hiperplasi, rasa sakit, dan perdarahan. $^{7}$

Perubahan hormon dan vaskular yang berhubungan dengan kehamilan dapat memicu respon gingiva terhadap bakteri plak. Kehamilan dapat memperburuk keadaan yang telah ada. Beberapa studi mengatakan bahwa gingivitis merupakan hasil dari meningkatnya hormon seks ibu hamil. Progesteron menyebabkan meningkatnya eksudasi dan pengaruh kapilaritas sel - sel endotelial. Progesteron juga mempengaruhi biosintesis prostaglandin di gingiva, pada masa kehamilan cell-mediated response ditekan, yang berperan dalam meningkatnya respon terhadap plak. Selain itu resiko bakteri anaerob ke aerob pada 
jaringan subgingival meningkat secara signifikan dari minggu ke-13 hingga ke-16 kehamilan dan bertahan hingga trimester III. $^{8}$

Faktor penyebab timbulnya gingivitis pada masa kehamilan dapat dibagi 2 bagian, yaitu penyebab primer dan sekunder. a. Penyebab primer: Iritasi lokal seperti plak merupakan penyebab primer gingivitis masa kehamilan sama halnya seperti pada ibu yang tidak hamil, tetapi perubahan hormon yang menyertai kehamilan dapat memperberat reaksi peradangan pada gusi oleh iritasi lokal. Iritasi lokal tersebut adalah kalkulus dan plak yang telah mengalami pengapuran, sisa - sisa makanan, tambalan kurang baik, gigi tiruan yang kurang baik. Saat kehamilan terjadi, perubahan dalam pemeliharaan kebersihan gigi dan mulut bisa disebabkan oleh timbulnya perasaan mual, muntah, perasaan takut ketika menggosok gigi karena timbul peradangan pada gusi atau ibu terlalu lelah dengan kehamilannya sehingga malas mengosok gigi. Keadaan ini dengan sendirinya akan menambah penumpukan plak sehingga memperburuk keadaan. b. Penyebab sekunder : kehamilan merupakan keadaan fisiologis yang menyebabkan perubahan keseimbangan hormonal, terutama perubahan hormon esterogen dan progesteron pada masa kehamilan mempunyai efek bervariasi pada jaringan, diantaranya pelebaran pembuluh darah yang mengakibatkan bertambahnya aliran darah sehingga gusi menjadi lebih merah, bengkak dan mudah mengalami pendarahan. Akan tetapi, jika kebersihan gigi dan mulut terpelihara dengan baik selama kehamilan, perubahan mencolok pada jaringan gusi jarang terjadi. ${ }^{2}$

Tujuan penelitian ini untuk mengetahui adanya hubungan pengetahuan tentang kebersihan gigi dan mulut pada ibu hamil dengangingivitis precnancy di Puskesmas Ranomut.

\section{METODE}

Jenis penelitian ini bersifat analitik dengan pendekatan cross sectional study, dimana data yang menyangkut variabel bebas dan variabel terikat dikumpulkan dalam waktu yang bersamaan. Tempat penelitian dilakukan pada Puskemas Ranomuut Manado pada bulan Juni 2018. Variabel beabas pada penelitian ini yaitu tingkat pengetahuan ibu hamil tentang kebersihan gigi dan mulut, sedangkan variabel terikat yaitu gingivitis pregnancy.

Jumlah populasi sebanyak 143 orang ibu hamil dengan jumlah sampel sebanyak 59 orang yang diambil dengan cara metode accidental sampling dengan kriteria inklusi : bersedia menjadi responden, hadir pada saat penelitian dan tidak dalam keadaan sakit.

Pengumpulan data dilakukan dengan menggunakan kuesioner tentang kebersihan gigi dan mulut pada saat kehamilan yang berjumlah 9 pertanyaan dengan kriteria jawaban, apabila menjawab benar diberi nilai 2 dan bila salah diberikan nilai 1 , dengan kriteria pengetahuan baik : nilai 14 -18 dan pengetahuan kurng baik : nilai 9 13. Pregnancy Gingivitis diukur dengan menggunakan indeks gingival dengan skor 0 ( sehat, 1 (ringan), 2 (sedang), 3 (berat).

Instrumen penelitin : kuesioner, format pemeriksaan dan diagnosa set (kaca mulut, sonde, ekskavator, pinset), periodontal prob, nirbeken dan kapas alkohol.

Data yang diperoleh kemudian ditabulasi dengan menggunakan uji statistik yaitu uji Correlation Kendall Tau yang diolah dengan menggunakan softwere computer statistik untuk mengetahui hubungan antara dua variabel dengan skala ordinal yaitu pengetahuan ibu hamil tentang kebersihan gigi dan mulut dengan gingivitis pregnancy. ${ }^{9}$

\section{HASIL}

Penelitian ini dilakukan pada Puskesmas Ranomut Kota Manado pada bulan Juni 2018 dengan jumlah sampel 59 orang ibu hamil. 


\section{a. Karakteristik Responden}

Distribusi responden menurut golongan umur, tingkat pendidikan, pekerjaan dan umur kehamilan dapat dilihat pada tabel 1. Dibawah ini.

Tabel.1. Distribusi frekuensi menurut golongan umur, tingkat pendidikan, pekerjaan dan umur kehamilan

\begin{tabular}{|c|c|c|}
\hline Variabel & $\mathbf{n}$ & $\%$ \\
\hline \multicolumn{3}{|l|}{ Umur } \\
\hline 17 - 20 Tahun & 18 & 30,5 \\
\hline $21-25$ Tahun & 15 & 25,4 \\
\hline $26-30$ Tahun & 16 & 27,1 \\
\hline 31 - 35 Tahun & 6 & 10,1 \\
\hline $36-40$ Tahun & 3 & 5,0 \\
\hline 41 - 45 Tahun & 1 & 1,6 \\
\hline \multicolumn{3}{|l|}{ Pendidikan } \\
\hline S1 & 1 & 1,6 \\
\hline SMA & 44 & 74,5 \\
\hline SMP & 14 & 23,7 \\
\hline \multicolumn{3}{|l|}{ Pendidikan } \\
\hline PNS & 2 & 3,3 \\
\hline Swasta & 6 & 10,1 \\
\hline IRT & 51 & 86,4 \\
\hline \multicolumn{3}{|l|}{ Umur Kehamilan } \\
\hline \multicolumn{3}{|l|}{ Trisemester I } \\
\hline Trisemester II & 6 & 10,1 \\
\hline \multirow[t]{2}{*}{ Trisemester III } & 26 & 44,0 \\
\hline & 27 & 45,7 \\
\hline Total & 59 & 100 \\
\hline
\end{tabular}

Distribusi responden menurut golongan umur pada tabel 1 menunjukkan jumlah responden terbanyak pada golongan umur $17-20$ tahun yaitu sebanyak 18 orang $(30,5 \%)$, tingkat pendidikannya yang paling banyak adalah SMA 44 orang $(74,5 \%)$, distribusi responden menurut pekerjaan yang paling banyak sebagai IRT 51 orang $(86,4 \%)$, menurut umur kehamilan paling banyak pada trimester III (7- 9 bulan) 27 orang $(45,7 \%)$,

\section{b. Distribusi Responden menurut tingkat pengetahuan tenatang kebersihan gigi dan mulut.}

Distribusi responden menurut tingkat pengetahuan tentang kebersihan gigi dan mulut dapat dilihat pada tabel 2 dibawah ini:

Tabel 2. Distribusi Responden Menurut Tingkat Pengetahuan Ibu Hamil Tentang Kebersihan Gigi Dan Mulut

\begin{tabular}{ccc}
\hline Pengetahuan & n & \% \\
\hline Baik & 16 & 27,1 \\
Kurang Baik & 43 & 72,8 \\
\hline Total & 59 & 100 \\
\hline
\end{tabular}

\section{c. Distribusi Responden Menurut Status Gingivitis}

Distribusi responden menurut status gingivitis dapat dilihat pada tabel 3 dibawah ini:

Tabel 3. Distribusi Responden Menurut Status Gingivitis

\begin{tabular}{ccc}
\hline Status Gingivitis & $\mathrm{n}$ & $\%$ \\
\hline Sehat & 0 & 0 \\
Peradangan ringan & 23 & 38,9 \\
Peradangan sedang & 25 & 42,3 \\
Peradangan buruk & 11 & 18,6 \\
\hline Total & 59 & 100 \\
\hline
\end{tabular}

Pada tabel.3 diatas menunjukkan hasil pemeriksaan status gingivitis menyatakan bahwa sebagian besar responden termasuk dalam kriteria peradangan sedang dengan jumlah 25 orang $(42,3 \%)$

\section{d. Tabel Silang Variabel Pengetahun Kebersihan Gigi Dan Mulut Dengan Gingivitis Pregnancy}

Tabel silang variabel pengetahuan kebersihan gigi dan mulut dengan gingivitis pregnancy dapat dilihat pada tabel 4. dibawah ini: 
Tabel 4. . Tabel Silang Hubungan Variabel Pengetahun Ibu Hamil Tentang Kebersihan Gigi

Dan Mulut DenganGingivitis Pregnancy

\begin{tabular}{|c|c|c|c|c|c|c|c|c|c|c|}
\hline \multirow{3}{*}{$\begin{array}{l}\text { Penget } \\
\text { ahuan }\end{array}$} & \multicolumn{8}{|c|}{ Status Gingivitis } & \multirow{2}{*}{\multicolumn{2}{|c|}{ Total }} \\
\hline & \multicolumn{2}{|c|}{$\begin{array}{l}\text { Seha } \\
\mathrm{t}\end{array}$} & \multicolumn{2}{|c|}{ Ringan } & \multicolumn{2}{|c|}{ Sedang } & \multicolumn{2}{|c|}{ Buruk } & & \\
\hline & $\mathrm{n}$ & $\%$ & $\mathrm{n}$ & $\%$ & $\mathrm{n}$ & $\%$ & $\mathrm{n}$ & $\%$ & $\mathrm{n}$ & $\%$ \\
\hline Baik & - & - & 13 & 22,0 & 3 & 5,0 & - & - & 16 & 27 \\
\hline $\begin{array}{l}\text { Kuran } \\
\text { g Baik }\end{array}$ & - & - & 10 & 16,9 & 22 & 37,2 & 11 & $\begin{array}{l}18 \\
, 6\end{array}$ & 43 & $\begin{array}{l}1 \\
72, \\
8\end{array}$ \\
\hline Total & - & - & 23 & 38,9 & 25 & 42,2 & 11 & $\begin{array}{l}18 \\
6\end{array}$ & 59 & 100 \\
\hline
\end{tabular}

Pada tabel.4 menunjukkan bahwa persentase terbesar pada kriteria pengetahuan kurang baik terhadap gingivitis sedang yaitu sebanyak 22 responden $(37,2 \%)$.

\section{e. Analisis Data Menggunakan Uji Correlation Kendall Tau}

Analisis data menggunakan uji Correlation Kendall Tau dapat dilihat pada tabel 5. sebagai berikut:

Tabel 5.. Analisis Data Menggunakan Uji Correlation Kendall Tau

\begin{tabular}{lcc}
\hline & \multicolumn{2}{c}{ Skor Gingivitis } \\
\cline { 2 - 3 } Skeregnancy \\
\cline { 2 - 3 } Pengetahuan & $r$ & $-0,441$ \\
& $p$ & 0,000 \\
& $\mathrm{n}$ & 59 \\
\hline
\end{tabular}

Hasil analisis menggunakan uji Correlation Kendall Tau didapatkan nilair sebesar -0,441dengan kekuatan korelasi cukup yaitu antara nilai 0,400,599 dengan nilai $p$ sebesar 0,000 lebih kecil dari nilai $\alpha=0,05$ sehingga terdapat nilai korelasi yang bermakna atau signifikan antara variabel pengetahun kebersihan gigi dan mulutdengan variabel gingivitis pregnancy, dengan arah korelasi negatif (-) yang berarti semakin besar nilai pengetahuan kebersihan gigi dan mulut maka semakin kecil nilai gingivitis pregnancy

\section{PEMBAHASAN}

Pada wanita hamil, biasanya dapat terjadi perubahan - perubahan sebagai berikut: a. perubahan fisiologi (perubahan normal pada tubuh) yaitu penambahan berat badan, pembesaran pada payudara, bisa terjadi pembekakan pada tangan dan kaki, terutama pada usia kehamilan trimester III (6 9 bulan), perubahan pada kulit karena adanya kelebihan pigmen pada tempat - tempat tertentu (pipi, sekitar hidung, sekitar puting, susu dan diatas tulang kemaluan sampai pusar), dapat terjadi penurunan $\mathrm{pH}$ saliva. b. Perubahan psikis (perubahan yang berhubungan dengan kejiwaan) sering terjadi pada usia kehamilan muda (trimester I atau 0 - 3 bulan) meliputi : Morning sickness (rasa mual dan ingin muntah terutama pada waktu pagi hari), rasa lesu, lemas, dan terkadang hilang selara makan, perubahan tingkah laku diluar kebiasaan sehari - hari seperti "ngidam". 5

Faktor sosial dan budaya juga mempengaruhi kehamilan dari segi gaya hidup, adat istiadat dan fasilitas kesehatan. Gaya hidup sehat adalah gaya hidup yang digunakan ibu hamil. Seorang ibu hamil sebaiknya tidak merokok, bahkan kalau perlu selalu menghindari asap rokok, kapan dan dimana pun ia berada. Perilaku makan juga harus diperhatikan, terutama yang berhubungan dengan adat istiadat. ${ }^{2}$

Jika ada makanan yang dipantang adat padahal baik untuk gizi ibu hamil, maka sebaiknya tetap dikonsumsi. Demikian juga sebaliknya yang tak kalah penting adalah personal hygiene. Ibu hamil harus selalu menjaga kebersihan dirinya, mengganti pakaian dalamnya setiap kali terasa lembab, menggunakan bra yang menunjang payudara, dan pakaian yang menyerap keringat. ${ }^{10}$

Menurut Hearther Jaret, dari University of North Carolina di Chapel Hill, Amerika Serikat dalam presentasinya di Asosiasi Internasional untuk penelitian gigi, menyatakan bahwa Ibu hamil yang mengalami sakit gigi kronis atau berat dan 
menderita infeksi periodontal, beresiko untuk melahirkan bayi berat lahir rendah (BBLR) karena pertumbahannya terganggu. ${ }^{2}$

Keadaan gingivitis pada ibu hamil kurang mendapat perhatian baik dari individu yang bersangkutan maupun dokter kandungan. Penyakit periodontal yang tidak dirawat pada wanita hamil merupakan salah satu faktor resiko kelahiran sebelum waktunya (<37 minggu) dan bayi lahir dengan berat kurang $(<2500 \mathrm{~g}){ }^{11}$ Pada penelitian ini dilakukan pengujian untuk mengetahui seberapa kuatnya hubungan pengetahuan kebersihan gigi dan mulut terhadap gingivitis pregnancy. Aspek pengetahuan pencegahan gingivitis, penyebab gingivitis dan tujuan menyikat gigi yang dinilai yaitu tahu (know) dan memahami (comprehension) dan selanjutnya dikorelasikan dengan gingivitis pregnancy.

Variabel menurut tingkat pengetahuan ibu hamil tentang kebersihan gigi dan mulut pada tabel.2 terdapat pengetahuan responden dengan kriteria baik 16 orang $(27,1 \%)$ dan kriteria kurang baik 43 orang $(72,8 \%)$. Hal ini karena kurangnya perhatian saat dilakukan pendidikan kesehatan gigi dan kurangnya membaca informasi - informasi yang ada di media sosial belum menyadari bahwa pentingnya pengetahuan tentang kebersihan gigi dan mulut.

Variabel distribusi responden menurut status gingivitis pada tabel.3 yang di peroleh dari hasil pemerikasaan menyatakan bahwa responden termasuk dalam kriteria ringan 23 orang $(38,9 \%)$, kriteria sedang 25 orang $(42,3 \%)$ dan kriteria buruk 11 orang $(18,6 \%)$. Hal ini disebabkan karena adanya peningkatan hormon esterogen dan pregesteron selama periode kehamilan serta adanya vaktularisasi yang menyebabkan respon berlebih terhadap faktor iritasi lokal (plak) yang menimbulkan kelainan dalam rongga mulut seperti, peradangan pada gusidan epulis gravidarium atau benjolan pada gusi antara 2 gigi. ${ }^{5}$ dan ibu hamil hanya tahu dan memahami tetapi tidak diikuti dengan rasa perduli dan tindakan untuk menjaga kebersihan gigi dan mulut sehingga status gingivitis ibu hamil masih banyak dalam kategori sedang. Tahu saja tidak cukup dan perludiikuti dengan rasa perduli daan tindakan. $^{12}$

Tabel silang variabel pengetahuan ibu hamil tentang kebersihan gigi dan mulut dengangingivitis pregnancy pada tabel.4 terdapat pada kriteria pengetahuan baik dengan status gingivitisringan yaitu 13 orang $(22,0 \%)$, sedangkan pengetahuan baik status gingivitis sedang 3 orang $(5,0 \%)$. Pengetahuan dari tenaga kesehatan maupun media sosial belum merubah pola perilaku ibu hamil dalam memelihara kebersihan gigi dan mulut sehingga pada penelitian ini didapatkan lebih banyak ibu hamil memiliki pengetahuan yang kurang baik dengan status gingivitis yang sedang. Sedangkan kriteria pengetahuan kurang baik dengan status gingivitisringan 10 orang (16,9\%), pengetahuan kurang baik dengan status gingivitis sedang 22 orang $(37,2)$ dan pengetahuan kurang baik dengan status gingivitis buruk 11 orang (18,6\%). Dari data ini persentase pengetahuan baik dengan status gingivitis sehat masih sangat kurang dan masih banyak didapatkannya ibu hamil yang memiliki pengetahuan kurang sehingga masih dibutuhkan pendidikan tentang kesehatan gigi untuk menambah pengetahuan ibu hamil untuk mencapai kebersihan gigi dan mulut yang diharapakan.Pendidikan tentang kesehatan gigi dan mulut serta bimbingan cara memelihara kebersihan gigi dan mulut adalah salah satu cara yang bisa dilakukan untuk mengubah pola perilaku ibu hamil untuk menjaga kebersihan gigi dan mulut karena perilaku sangat berperan penting dan merupakan faktor dominan yang mempengaruhi derajat kesehatan individu, kelompok atau masyarakat. $^{13}$

Analisis data pada penelitian ini menggunakan uji Correlation Kendall Tau parameternya berada pada 2 nilai yaitu nilai korelasi dan nilai signifikan. Nilai correlation kendall tau dengan tanda -/+ menandakan arah korelasi, dengan tingkat koefisien korelasi hubungan masing-masing variabel 
menggunakan nilai $0,00-0,19$ sangat rendah, 0,200,399 rendah, 0,40-0,599 cukup, 0,60-0,799 kuat dan 0,80-1,000 sangat kuat. Nilai signifikan dinyatakan berhubungan jika nilai $\alpha=<0,05$ tanpa menunjukan arah korelasi (Machali, 2015). Berdasarkan hasil uji Correlation Kendall Tau antara pengetahuan tentang kebersihan gigi dan mulut dengan gingivitis pregnancy di peroleh nilai korelasi sebesar $-0,441$ berada diantara nilai 0,40 0,599 yaitu korelasi cukup dengan arah korelasi negatif (-) dengan nilai $p$ sebesar 0,000 yaitu kurang darinilai $\alpha=0,05$ yang berarti hipotesis nol (Ho) tidak di terima dan hipotesis alternatif $\left(\mathrm{H}_{1}\right)$ di terima dengan pernyataan bahwa pengetahuan tentang kebersihan gigi dan mulut dengan gingivitis pregnancy dengan arah korelasi negatif (-) dimana semakin tinggi pengetahuan maka status gingivitis ssemakin rendah. Hasil penelitian menunjukan pengetahun kebersihan gigi dan mulut dengan gingivitis pregnancy masih memiliki nilai korelasi cukup dengan nilai korelasi berhubungan. Hal ini dapat disebabkan karena ibu hamil memiliki status gingivitis ssedang lebih banyak dibandingkan dengan status gingivitissehat dan ibu hamil kurang memiliki pengetahuan yang baik.

Hal ini sejalan dengan penelitian sebelumnya (Hidayati, 2012) tentang pengaruh kebersihan gigi dan mulut denganstatus gingivitis pada ibu hamilsebagian besar ibu hamil mengalami gingivitis sedang yaitu sebanyak 70\%, mengalami gingivitis berat $18,6 \%$ dan sisanya mengalami gingivitis ringan $11,4 \%{ }^{4}$

Menurut Notoatmodjo (2010) bahwa perilaku keseahatan dibagi menjadi 3 domain, yaitu pengetahuan, sikap dan tindakan. Ini berarti bahwa tidak hanya pengetahuan yang dapat membentuk prilaku seseorang. Pengetahuan ibu hamil tentang kebersihan gigi dan mulut sangat menentukan status gingivitis, senakin baik tingkat pngetahuan maka semakin baik pula tindaakan seseorang dalam menjaga kebersihan gigi dan mulut. ${ }^{15}$

\section{KESIMPULAN}

Berdasarkan penelitian yang dilakukan di Poli KIA/KB Puskesmas Ranomut diperoleh hasil penelitian bahwa ada hubungan yang cukup antara pengetahuan tentang kebersihan gigi dan mulu dengan gingivitis pregnancy.

\section{SARAN}

a. Bagi Institusi Pelayanan (Puskesmas) diharapkan lebih meningkatkan kesehatan gigi dan mulut ibu hamil dengan memberikan penyuluhan tentang pentingnya menjaga kesehatan dan kebersihan mulut selama kehamilan, memberi motivasi dan nasehat kepada ibu hamil untuk memeriksakan kesehatan rongga mulutnya ke dokter gigi bersamaan pada saat pemeriksaan kehamilan.

b. Bagi Populasi Penelitian untuk lebih meningkatkan kesadaran agar selalu menjaga kebersihan dan kesehatan gigi dan mulutnya.

c. Sebagai bahan referensi dan hasil penelitian dapat digunakan sebagai dasar atau acuan dalam melaksanakan penelitian selanjutnya serata dapat digunakan sebagai pedoman dalam penulisan Karya Tulis Ilmiah.

\section{DAFTAR PUSTAKA}

1. Lestari. (2010). Ibu Hamil dan Menyusui. Barokah Press. Yogyakarta

2. Hermawan, R. (2010). Menyehatkan Daerah Mulut. Buku Biru. Yogyakarta

3. Saputri, D., Afrina \& Shalina. R. K. ( 2016). Perilaku Pemeliharaan Kesehatan Gigi dan Mulut Ibu Hamil di Wilayah Kerja Puskesmas Kopelma Darussalam Banda Aceh. J. Syiah Kuala dent Sec. 2016 1(1):85-90.

4. Hidayati, Kuswardani \& Rahayu, G. (2012). Pengaruh Kebersihan Gigi dan Mulut denagn Status Gingivitis Pada Ibu Hamil di Wilayah Kerja Puskesma Andalas Kecamatan Padang 
Timut Kota Padang. Majalah Kedokteran Andalas. 36 (36):215-224

5. Kementerian Kesehatan, RI.(2012). Pedoman Pemeliharaan Kesehatan Gigi dan Mulut Ibu Hamil dan Anak Usia Balita Bagi Tenaga Kesehatan di Fasilitas Kesehatan. Kementrian Kesehatan RI.

6. Rose, L.F., Sex Hormonal Imbalances, Oral Manifestation and Dental Tretment. In: Genco, R.J., Goldman, H.M., Cohen, D.W., eds. Contemporary Periodontic. Saint Louis: Mosby. $1990: 61-2$.

7. Gursoy, M., Pajukanta, R., Sorsa, T., \& Kononen, E. (2008). Clinical Changes In Periodontium During Pregnancy and Postpartum. J Clin Periodontol. (35):576-83.

8. Habashneh, R., Guthmiller, J.M., Levy, S., Johnson, G.K., Squier, C., Dawson, D.V., \& Fang, Q. (2005). Factor Related To Utilization Of Deental Services During Pregnancy. J Clin Periodontol. (32): 815-821

9. Sugiyono. (2010). Statistik Nonparamentris untuk Penelitian. CV. ALFABETA. Bandung

10. Halsyah, D. (2015). Perubahan Psikologi Dan Fisiologi Terhadap Masa Kehamilan. http://diyahhalsyah.com/2015/03/makalahtentang-perubahan-psikologi-dan.html. Diakses tanggal 21 Juli 2018

11. Ferris, G.M. (1993). Alteratiaon In Female Sex Hormones: Their Effect On Oral Tissues And Dental Treatment. Compedium 14. Medline, Chemport.

12. Herijilianti, E., Indrani, T. S., Artini, S. (2002). Pendidikan Kesehatan Gigi. EGC. Jakarta.

13. Budiharto. (2009). Pengantar Ilmu Kesehatan dan Pendidikan Kesehatan Gigi. Buku Kedokterarn EGC. Jakarta.

14. Machali, I. (2015). Statistik Itu Mudah Menggunakan SPSS Sebagai Alat Bantu Statistik. Ladang Kata. Yogyakarta.

15. Notoatmodjo, S. (2010). Metodologi Penelitian Kesehatan. Rineka Cipta. Jakarta. 